WellBeing International

WBI Studies Repository

1986

\title{
The Significance of Alternative Techniques in Biomedical \\ Research: An Analysis of Nobel Prize Awards
}

Martin Stephens

The Humane Society of the United States

Follow this and additional works at: https://www.wellbeingintlstudiesrepository.org/acwp_arte

Part of the Bioethics and Medical Ethics Commons, Design of Experiments and Sample Surveys Commons, and the Laboratory and Basic Science Research Commons

\section{Recommended Citation}

Stephens, M. (1986). The significance of alternative techniques in biomedical research: An analysis of Nobel Prize awards. In M.W. Fox \& L.D. Mickley (Eds.), Advances in animal welfare science 1986/87 (pp. 19-31). Washington, DC: The Humane Society of the United States.

This material is brought to you for free and open access by WellBeing International. It has been accepted for inclusion by an authorized administrator of the WBI Studies Repository. For more information, please contact wbisr-info@wellbeingintl.org.

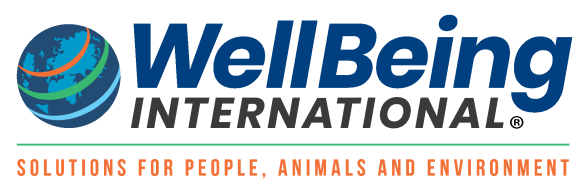




\title{
THE SIGNIFICANCE OF \\ ALTERNATIVE TECHNIQUES IN BIOMEDICAL RESEARCH: AN ANALYSIS OF NOBEL PRTZE AWARDS ${ }^{1}$
}

\author{
Martin Stephens ${ }^{2}$
}

\section{Introduction}

The current controversy over the use of animals in research has put the biomedical and psychological communities on the defensive. Their main defense has been to emphasize the health benefits to humans from animal research (e.g., Miller 1985; Gay undated).

This defense has been challenged on scientific grounds in at least two ways. First, critical assessments of various fields of animal research have revealed that claims of health benefits are grossly exaggerated (Drewitt and Kani 1981; Kuker-Reines 1982; Giannelli 1985; Sharpe 1985; Reines 1986, undated; Stephens 1986a; Anonymous 1986). A second and complementary response is to argue that, whatever the benefits have been, the use of animals should be replaced to the fullest extent possible by alternative methods.

Alternatives include the three Rs of replacement, reduction, and refinement (Russell and Burch 1959), that is, methods that completely replace the use of animals in a procedure, that reduce animal use, and refine procedures so that pain, suffering, or deprivation are lessened (Stephens 1986b). Reduction and refinements are considered interim steps toward the ultimate goal of the complete replacement of laboratory animals with nonanimal methods.

The "alternatives approach" consists of developing and employing methods specifically designed as alternatives. The aim of the approach is to determine the extent to which alternatives can replace traditional uses of animals. This aim has an ethical and compassionate appeal that is being bolstered by recent scientific advances in developing alternatives (Stephens 1986b).

The alternatives approach was first discussed comprehensively in 1959 by Russell and Burch (1959). Before this, some alternative methods already had been developed but were employed almost exclusively for scientific reasons, with humane considerations being overlooked. The alternatives approach advocates both scientific and humane considerations.

Perhaps because of the recentness of this approach-indeed, of some of the alternatives themselves - animal advocates have largely overlooked the past achievements of alternative techniques in research. One of the few 
historical examples that proponents of alternatives have cited is the role of cell culture in polio research (Rowan 1979). The present paper documents many others.

Table 1 lists methods that are considered here to be alternatives. Some of these methods are readily classified according to the three Rs. For example, human studies and physicochemical assays are replacements. However, other methods can fall into more than one category. For example, the method of using less sentient organisms is a replacement when microorganisms or plants are employed instead of multicellular animals, while the method will usually be a refinement when invertebrates are employed instead of vertebrates.

The importance of alternative methods in the history of biomedical research can be inferred from Nobel Prize awards in medicine or physiology. These awards are generally believed to recognize research "of the highest caliber, the most enduring influence, and the most importance to biomedical science" according to the National Academy of Sciences (1985). Before turning to an analysis of these awards, we should note that any comparison of the historical significance of alternative methods and traditional animal research is likely to be biased against alternatives for several reasons, including the acceptance of animal methods as the main paradigm of research, the historical paucity of ethical and compassionate concern for laboratory animals, and the newness of some alternative methods. Hence we should not expect alternative methods to have outshined traditional animal methods in the history of biomedical research.

Table 1. Alternative Methods

1. Human Studies
a. epidemiological
b. clinical (observations as weil as studies)
c. post-mortem

2. In vitro studies
a. studies of sub-cellular components
b. short-term (less than $24 \mathrm{hr}$.) studies of cells or tissues
c. studies of cells or tissue in culture

3. Mathematical and computer modeling studies

4. Studies of less sentient organisms
a. vertebrate embryos
b. invertebrates
c. microorganisms
d. plants

5. Physicochemical assays of biological substances

6. Miscellaneous methods
a. naturalistic studies of animals
b. clinical studies of animals
c. studies of mechanical models 


\section{Methods}

Seventy-six Nobel Prizes in medicine or physiology have been awarded between 1901, the inaugural year, and 1985. These awards were classified into two categories, alternative and nonalternative, depending on whether or not alternative methods made a major contribution to the research. The major contributions to projects in the non-alternative category were made by in vivo studies of vertebrates. Most projects clearly fell into one or the other category. It is recognized that the classification of some projects is arguable, but the conclusions presented below would hold regardless of how these few cases were judged.

The classification scheme examines only the prize-winning research itself, and does not consider the pre-existing foundation of biomedical knowledge necessary to conduce the research (see Comroe and Dripps 1976).

Sufficient information was available to classify all but two awards (those given in 1906 and 1924). When an award was divided among two or more research projects, it was classified in the alternative category as long as alternative techniques made a major contribution to at least one project. Eight awards were of this kind and are identified as such in the Results section.

Any award-winning project in the alternative category is a testament to the power of the techniques advocated by animal protectionists. However, studies that involved alternative techniques can be subdivided into two categories, namely, those that could have been conducted on intact vertebrates, but which were not, and those that necessarily could not. Although projects in the former subcategory hold more promise for animal advocates, projects in the latter category should also be welcomed by animal advocates as well as others for contributing to biomedical knowledge in ways that traditional animal methods could not. Examples of these projects include descriptive studies of molecular biology, in which sub-cellular components are researched.

It is recognized that this secondary classification, as with the primary classification, involves subjectivity in some cases.

\section{Results}

Surprisingly, fully two-thirds (50) of the Nobel Prizes fall into the alternatives category. Table 2 provides a brief description of these awards and lists the alternative techniques associated with each one.

I emphasize that the classification of a project in the alternative category does not mean that intact, vertebrate animals were not used. Rather, this designation indicates that alternative methods were the key, even though in vivo vertebrate methods also may have been involved and may have played an important role.

Nicolle's research on the spread of typhus, awarded the Nobel Prize in 1928, illustrates this distinction. Nicolle, a hospital physician, observed that people who touched new typhus patients or their clothes contracted typhus themselves. Yet once the patients were admitted to the hospital, contagion ceased. In his Nobel lecture, Nicolle noted: 
I asked myself what happened between the hospital door and the sickroom. What happened was this: the typhus patient was relieved of his clothes and linen, and was shaved and washed. The agent of the contagion was therefore something attached to the skin, to his linen, and something of which soap and water rid him. This could only be the louse....

If it had not been possible to reproduce the malady in animals and consequently to verify the hypothesis, this simple determination would have sufficed to make clear the mode of propagation of typhus (quoted in Sourkes, 1966, p. 134).

Hence, Nicolle himself stated that his clinical observations were the key to identifying the louse as the agent of typhus transmission. This discovery, in turn, was the main reason for Nicolle's receipt of the prize (Sourkes 1963). ${ }^{3}$

Figure 1 shows the prevalence of alternative projects among the Nobel Prize winners throughout this century. The prevalence has increased steadily during the past 70 years. During the last 20 years, 19 of the 20 prizes were awarded to projects in the alternative category! This has resulted primarily from the increasing prominence of in vitro studies, including molecular and biochemical studies of sub-cellular components and studies of cells and tissues in culture.

The 50 studies in the alternatives category were further classified into those that could have been conducted on intact vertebrates and those that necessarily could not (see Methods). The projects fell about equally in both subcategories (24 vs. 26, respectively).

The award-winning projects in either subcategory form a diverse collection. Some projects were of practical value in the fight against diseases. Examples include the discovery of the insect vector of malaria (awarded the Nobel Prize in 1902), the discovery of the louse as the transmitter of typhus (1928), the discovery of penicillin (1945), the production of a vaccine against yellow fever (1917), the discovery of a hormonal treatment for prostate and breast cancer (1966), and the elucidation of the mechanism for familial hypercholesterolemia (1985). The successful cultivation of the polio virus in tissue culture (1954) paved the way for the development of effective polio vaccines.

Other award-winning projects using alternative methods made significant contributions to basic biology. Examples include the discovery that genes regulate chemical processes - the one gene, one enzyme principle (1958), the discovery of the double helix structure of DNA (1962), and the discovery of the interaction between tumor viruses and the genetic material of cells (1975).

Still other projects developed techniques that have rapidly become invaluable in biomedical research. These developments include radioimmunoassay (1977), restriction enzymes (1978), computer-assisted tomography (1979), and monoclonal antibodies (1984).

Let us examine the most recent, award-winning project as an example of the kinds of studies that constitute such highly regarded research. Brown and Goldstein were honored in 1985 for elucidating the fundamental mechanism of familial hypercholesterolemia (FH), a genetic disorder of cholesterol metabolism that predisposes carriers to coronary heart disease. Much of Brown and Goldstein's research was conducted in vitro. Fibroblasts from patients homozygous for FH were cultured and shown to have abnormal 


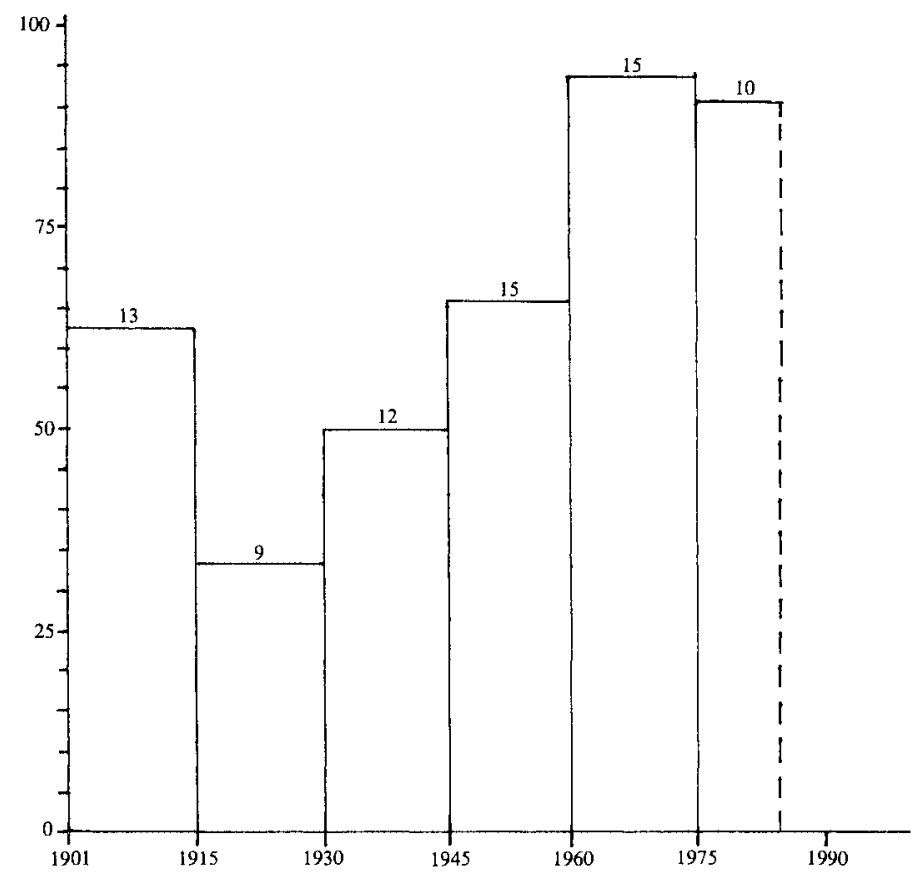

Figure 1. Percentages of twentieth century Nobel Prizes in medicine or physiology awarded to projects that involved major contributions from alternative techniques. (Numbers atop bars indicate sample sizes.)

cholesterol metabolism and cholesterol-associated receptors. The pathway of cholesterol through the cell, including the critical step of receptor-mediated endocytosis, was worked out.

Molecular studies on patient-derived material showed the correspondence between the structure and function of the receptors and also identified various mutations that led to defective receptors.

In addition to these in vitro studies, Brown and Goldstein's work also involved clinical studies. A young patient was homozygous for $\mathrm{FH}$ and therefore lacked functional cholesterol-associated receptors. The patient had very high cholesterol levels and severe coronary arteriosclerosis. A liver transplant seems to have corrected the receptor problem and a heart transplant replaced the damaged heart.

Brown and Goldstein's work, which has implications beyond cholesterol metabolism and heart disease, was recently reviewed in Science (Motulsky 1986). That comprehensive article mentions animals studies in only one line, and these studies were apparently not conducted by Brown and Goldstein. 
Table 2. Research projects awarded Nobel Prizes that involved major contributions from alternative techniques.

$\begin{array}{lll}\text { Year } & \text { Winner } & \text { Techniqu } \\ 1902 & \text { R. Ross } & \text { LSO } \\ 1903 & \text { N. Finsen } & \text { IV } \\ 1907 & \text { C. Laveran } & \text { H } \\ 1908 & \text { E. Metchnikoff } & \\ 1909 & \text { T. Kocher } & \text { LSO, IV + } \\ 1910 & \text { A. Kossel } & \text { H } \\ 1911 & \text { A. Gullstrand } & \text { IV } \\ 1914 & \text { R. Bárány } & \text { H, MM } \\ & & \text { H }\end{array}$

1915-1918, 1921, 1925: No Prizes awarded

1927 J. Wagner-Jauregg M

$\begin{array}{lll}1928 & \text { C. Nicolle } & \text { H }+ \\ 1930 & \text { K. Landsteiner } & \text { IV } \\ 1931 & \text { O. Warburg } & \text { IV } \\ 1933 & \text { T. Morgan } & \text { LSO or IV } \\ 1935 & \text { H. Spemann } & \text { LSO }\end{array}$

1937 A. von Szent-Györgyi IV

\section{Topic}

discovered insect vector of malaria (Anopheline mosquitoes) and other aspects of this disease treatment of diseases, especially lupus melgaries, with concentrated light radiation role of protozoa in causing diseases

immunity $(\mathrm{LSO}=$ larval starfish and water fleas)

physiology, pathology, and surgery of the thyroid gland protein chemistry of cells, including nucleic substances dioptrics of the eye physiology and pathology of the vestibular apparatus

malaria inoculation in treatment of dementia paralytica work on typhus discovery of the human blood groups nature and mode of action of the respiratory enzyme in yeast

role of the chromosome in heredity (fruit flies)

organizer effect in amphibian embryonic development biological combustion process, with special reference to vitamin $C$ and fumaric acid 
Table 2. Research projects awarded Nobel Prizes that involved major contributions from alternative techniques. (continued)

\begin{tabular}{|c|c|c|c|}
\hline Year & Winner & Technique $^{x}$ & Topic \\
\hline $\begin{array}{l}1940 \\
1944\end{array}$ & $\begin{array}{l}\text { 942: No Prizes } \\
\text { J. Erlanger } \\
\text { H. Gasser }\end{array}$ & IV & $\begin{array}{l}\text { differentiated functions of } \\
\text { single nerve fibers }\end{array}$ \\
\hline 1945 & Fleming $^{2}$ & $\mathrm{IV}+$ & discovery of penicillin \\
\hline 1946 & H. Muller & LSO & $\begin{array}{l}\text { production of mutations by } \\
\text { X ray (LSO = fruit fly) }\end{array}$ \\
\hline 1948 & P. Müller & $\mathrm{LSO}$ & $\begin{array}{l}\text { efficiency of DDT as a contact } \\
\text { poison against several } \\
\text { species of insects }\end{array}$ \\
\hline 1949 & E. Moniz ${ }^{2}$ & $\mathrm{H}$ & $\begin{array}{l}\text { therapeutic value of a } \\
\text { psychosurgical procedure in } \\
\text { certain psychoses }\end{array}$ \\
\hline 1951 & M. Theiler & $\mathrm{IV}+$ & vaccine against yellow fever \\
\hline 1953 & $\begin{array}{l}\text { H. Krebs } \\
\text { F. Lipmann }\end{array}$ & IV & $\begin{array}{l}\text { citric acid cycle and } \\
\text { coenzyme } A \text { and its role in } \\
\text { intermediary metabolism }\end{array}$ \\
\hline 1954 & $\begin{array}{l}\text { J. Enders } \\
\text { F. Robbins } \\
\text { T. Weller }\end{array}$ & $\mathrm{IV}+$ & $\begin{array}{l}\text { cultivation of poliomyelitis } \\
\text { viruses in tissue culture }\end{array}$ \\
\hline 1955 & H. Theorell & IV & $\begin{array}{l}\text { nature and mode of action } \\
\text { of oxidizing enzymes }\end{array}$ \\
\hline 1956 & $\begin{array}{l}\text { A. Courand } \\
\text { W. Forssmann } \\
\text { D. Richards }\end{array}$ & $\mathrm{H}$ & $\begin{array}{l}\text { heart catheterization and } \\
\text { pathological changes in the } \\
\text { circulatory system }\end{array}$ \\
\hline \multirow[t]{2}{*}{1958} & $\begin{array}{l}\text { G. Beadle } \\
\text { E. Tatum }\end{array}$ & LSO & $\begin{array}{l}\text { genes regulate chemical } \\
\text { processes (bread mold) }\end{array}$ \\
\hline & J. Lederberg & LSO & $\begin{array}{l}\text { genetic recombination and } \\
\text { the organization of the } \\
\text { genetic apparatus of bacteria }\end{array}$ \\
\hline 1959 & $\begin{array}{l}\text { S. Ochoa } \\
\text { A. Kornberg }\end{array}$ & IV & $\begin{array}{l}\text { mechanisms of the biologi- } \\
\text { cal synthesis of RNA and DNA }\end{array}$ \\
\hline 1962 & $\begin{array}{l}\text { F. Crick } \\
\text { J. Watson } \\
\text { M. Wilkins }\end{array}$ & IV, PC & $\begin{array}{l}\text { molecular structure of } \\
\text { nucleic acids and its signifi- } \\
\text { cance for the transfer of } \\
\text { information in living material }\end{array}$ \\
\hline
\end{tabular}


Table 2. Research projects awarded Nobel Prizes that involved major contributions from alternative techniques. (continued)

\begin{tabular}{|c|c|c|c|}
\hline Year & Winner & 'Technique' & Topic \\
\hline 1963 & $\begin{array}{l}\text { J. Eccles } \\
\text { A. Hodgkin } \\
\text { A. Huxley }\end{array}$ & $\mathrm{IV}+$ & $\begin{array}{l}\text { ionic involvement in the } \\
\text { excitation and inhibition of } \\
\text { nerve cell membranes }\end{array}$ \\
\hline 1964 & $\begin{array}{l}\text { K. Bloch } \\
\text { F. Lynen }\end{array}$ & LSO, IV & $\begin{array}{l}\text { mechanism and regulation of } \\
\text { cholesterol and fatty acid } \\
\text { metabolism (LSO = yeast) }\end{array}$ \\
\hline 1965 & $\begin{array}{l}\text { F. Jacob } \\
\text { A. Lwoff } \\
\text { J. Monod }\end{array}$ & LSO & $\begin{array}{l}\text { genes that control activity of } \\
\text { other genes (LSO = bacteria } \\
\text { and viruses) }\end{array}$ \\
\hline 1966 & C. Huggins ${ }^{2}$ & $\mathrm{H}+$ & $\begin{array}{l}\text { hormonal treatment for } \\
\text { cancer of prostate and breast }\end{array}$ \\
\hline 1967 & $\begin{array}{l}\text { G. Wald }{ }^{2} \\
\text { K. Hartline }\end{array}$ & $\begin{array}{l}\mathrm{IV}(+?) \\
\mathrm{LSO}, \mathrm{H}(+?)\end{array}$ & $\begin{array}{l}\text { chemical and physiological } \\
\text { visual process in the eye } \\
\text { (LSO = Limulus) }\end{array}$ \\
\hline 1968 & $\begin{array}{l}\text { M. Nirenberg } \\
\text { R. Holley } \\
\text { H. Khorana }\end{array}$ & $\begin{array}{l}\text { IV } \\
\text { IV } \\
\text { IV }\end{array}$ & $\begin{array}{l}\text { interpretation of the genetic } \\
\text { code and its function in } \\
\text { protein synthesis }\end{array}$ \\
\hline 1969 & $\begin{array}{l}\text { M. Delbruck } \\
\text { A. Hershey } \\
\text { S. Luria }\end{array}$ & $\begin{array}{l}\mathrm{LSO} / \mathrm{IV} \\
\mathrm{LSO} / \mathrm{IV} \\
\mathrm{LSO} / \mathrm{IV}\end{array}$ & $\begin{array}{l}\text { replication mechanism and } \\
\text { genetic structure of } \\
\text { bacterial viruses }\end{array}$ \\
\hline 1970 & B. Katz ${ }^{2}$ & $\mathrm{IV}(+?)$ & $\begin{array}{l}\text { transmitters in nerve } \\
\text { terminals and the mechanism } \\
\text { of their storage, release, } \\
\text { and activation }\end{array}$ \\
\hline 1971 & E. Sutherland, Jr. & IV & $\begin{array}{l}\text { mechanisms of the action } \\
\text { of hormones }\end{array}$ \\
\hline 1972 & $\begin{array}{l}\text { R. Porter } \\
\text { G. Edelman }\end{array}$ & $\begin{array}{l}\text { IV } \\
\text { IV }\end{array}$ & $\begin{array}{l}\text { chemical structure of } \\
\text { antibodies }\end{array}$ \\
\hline 1973 & $\begin{array}{l}\text { K. von Frisch } \\
\text { K. Lorenz } \\
\text { N. Tinbergen }\end{array}$ & $\begin{array}{l}\mathrm{Mi}^{3} \\
\mathrm{Mi} \\
\mathrm{Mi}\end{array}$ & $\begin{array}{l}\text { organization and elicitation } \\
\text { of individual and social } \\
\text { behavior patterns }\end{array}$ \\
\hline 1974 & $\begin{array}{l}\text { A. Claude } \\
\text { G. Palade } \\
\text { C. de Duve }\end{array}$ & $\begin{array}{l}\text { IV } \\
\text { IV } \\
\text { IV }\end{array}$ & $\begin{array}{l}\text { structural and functional } \\
\text { organization of the cell }\end{array}$ \\
\hline 1975 & $\begin{array}{l}\text { R. Dulbecco } \\
\text { D. Baltimore } \\
\text { H. Temin }\end{array}$ & $\begin{array}{l}\text { IV }+ \\
\text { IV } \\
\text { IV }\end{array}$ & $\begin{array}{l}\text { interaction between tumor } \\
\text { viruses and the genetic } \\
\text { material of cells }\end{array}$ \\
\hline
\end{tabular}


Table 2. Research projects awarded Nobel Prizes that involved major contributions from alternative techniques. (continued)

\begin{tabular}{|c|c|c|c|}
\hline Year & Winner & Technique ${ }^{1}$ & Topic \\
\hline 1976 & B. Blumberg ${ }^{2}$ & $\mathrm{H}$ & $\begin{array}{l}\text { new mechanisms for the } \\
\text { origin and dissemination of } \\
\text { infectious disease }\end{array}$ \\
\hline \multirow[t]{2}{*}{1977} & R. Yalow & IV & $\begin{array}{l}\text { development of radio- } \\
\text { immunoassay and the } \\
\text { principles underlying it }\end{array}$ \\
\hline & $\begin{array}{l}\text { R. Guillemin } \\
\text { A. Schally }\end{array}$ & Mi4 & hypothalamic hormones \\
\hline 1978 & $\begin{array}{l}\text { W. Arber } \\
\text { H. Smith } \\
\text { D. Nathans }\end{array}$ & $\begin{array}{l}\mathrm{LSO} / \mathrm{TV} \\
\mathrm{LSO} / \mathrm{IV} \\
\mathrm{LSO} / \mathrm{TV}\end{array}$ & $\begin{array}{l}\text { discovery and application of } \\
\text { restriction enzymes } \\
\text { (LSO= bacteria and viruses) }\end{array}$ \\
\hline 1979 & $\begin{array}{l}\text { A.Cormack } \\
\text { G. Hounsfield }\end{array}$ & $\begin{array}{l}\mathrm{MM}, \mathrm{H} \\
\mathrm{MM}, \mathrm{H}+\end{array}$ & $\begin{array}{l}\text { development of the X-ray } \\
\text { diagnostic technique, } \\
\text { computer-assisted } \\
\text { tomography }\end{array}$ \\
\hline 1981 & R. Sperry ${ }^{2}$ & $\mathrm{H}+$ & $\begin{array}{l}\text { functions of the cerebral } \\
\text { hemispheres }\end{array}$ \\
\hline 1982 & $\begin{array}{l}\text { S. Bergstrom } \\
\text { B. Samuelsson } \\
\text { J. Vane }\end{array}$ & $\begin{array}{l}\mathrm{N}, \mathrm{PC} \\
\mathrm{IV}, \mathrm{H}+ \\
\mathrm{N}+\end{array}$ & $\begin{array}{l}\text { biochemistry and physiology } \\
\text { of prostaglandins }\end{array}$ \\
\hline 1983 & B.McClintock & LSO & $\begin{array}{l}\text { discovery of mobile genetic } \\
\text { elements (LSO = corn) }\end{array}$ \\
\hline 1984 & $\begin{array}{l}\text { C. Milstein } \\
\text { G. Kohler }\end{array}$ & IV & $\begin{array}{l}\text { development of a technique } \\
\text { for monoclonal antibody } \\
\text { formation }\end{array}$ \\
\hline 1985 & $\begin{array}{l}\text { M. Brown } \\
\text { J. Goldstein }\end{array}$ & IV, H & $\begin{array}{l}\text { cholesterol biochemistry } \\
\text { and hypercholesterolemia }\end{array}$ \\
\hline
\end{tabular}

${ }^{1} \mathrm{H}=$ human studies, $\mathrm{IV}=$ in vitro studies, $\mathrm{MM}=$ mathematical modeling, $\mathrm{PC}=$ physicochemical techniques, $\mathrm{LSO}=$ studies of less sentient organisms (vertebrate embryos, invertebrates, microorganisms, and plants), and $\mathrm{Mi}=$ miscellaneous. $+=$ in vivo studies of nonhuman vertebrates (nonembryos) also involved.

2 Award shared with researcher(s) whose work involved major contributions from non-alternative methods.

3 All three researchers conducted naturalistic, ethological studies.

${ }^{4}$ Biological material (hypothalami) derived from slaughterhouse animals.

${ }^{5}$ Award shared with N. Jerne for his theoretical contributions.

\section{Sources:}

Sourkes, TL. 1966. Nobel Prize Winners in Medicine and Pbysiology, 1901-1965. New York: Abelard-Schuman. Science. 1966-1984. Various articles on Nobel Prize winners.

Garfield, E. 1985. The 1984 Nobel Prize in Medicine is awarded to Niels K. Jerne, Cesar Milstein, and Georges J.F. Kohler for their contributions to immunology. Cument Contents, 11 November. 


\section{Discussion}

The number of major contributions that alternative techniques have made to Nobel Prize-winning research is astonishing. Most of the Nobel Prizes in medicine or physiology were awarded before the alternatives approach was first articulated in 1959, and this approach has yet to be embraced as a guiding principle of biomedical research. Undoubtedly, few if any awardwinning projects used alternative techniques out of concern for animals. Yet the adoption of alternative methods is welcome regardless of its underlying motivation. The adoption of alternatives solely for the sake of science increases expectations of what can be achieved if alternatives are adopted for the sake of animals as well.

As striking as the results are, even more awards would have gone to projects that used alternatives techniques if not for the traditional emphasis on in vivo vertebrate studies in biomedical research. For example, many animal researchers were skeptical of tissue-culture systems in the early days of this technique's existence. If not for this skepticism, tissue culture "might have been used to discover many of the vitamins, amino acids, and hormones" according to the National Academy of Sciences (1985). Tissue culture could have been used to discover the hormone insulin, for instance. Even human studies could have yielded this discovery. Yet the researchers who discovered insulin used traditional in vivo methods on dogs. They were awarded the Nobel Prize in 1923. This byproduct of tradition is often regarded as a triumph of animal research, yet other techniques could have done the job.

The results presented above contrast with statements made by defenders of traditional animal research. In the foreword to the latest compendium of the health benefits of animal research (Gay undated), William Raub of the National Institutes of Health (NIH) praises animal research and downplays alternative methods:

Research with laboratory animals has been so integral to the progress of biomedicine that it is difficult to exaggerate the contribution. Virtually every medical innovation of the last century - and especially the last four decadeshas been based to a significant extent upon the results of animal experimentation. Had laboratory scientists studied only relatively simple living systems such as invertebrates, microorganisms, and cell cultures or had clinical scientists lacked avenues of inquiry apart from human experimentation with all its necessary ethical constraints, mystery would reign in many areas where invaluable knowledge now exists (Raub, undated).

Clearly, the public is receiving a biased view of biomedical research from the animal research industry.

This industry has also provided a biased view of the importance of traditional animal experiments in Nobel Prizewinning biomedical research. The National Society for Medical Research (NSMR), a now-defunct industry group that defended animal research, identified all award-winning projects from 1901 to 1977 that used animals (NSMR, undated). At first glance, NSMR's list is impressive, totalling 36 prizes (out of a potential 58). However, NSMR's 
analysis is misleading for several reasons. First, although public outcry against the use of animals in research focuses primarily on vertebrates (indeed, mostly mammals and birds), NSMR's list includes several projects on invertebrates, including mosquitoes (1902), starfish and water fleas (1908), fruit flies (1933, 1958), and horseshoe crabs (1967/Hartline).

Second, NSMR's analysis did not distinguish between in vivo studies and alternative studies of animals. The latter include in vitro studies (1953, 1963, 1967/Wald, 1970, 1977), ethological studies (1973), and biochemical studies using normally discarded material from slaughterhouses (1977).

Third, no assessment was made of the importance of intact vertebrates in research projects that also involved alternative techniques. Hence, several projects are listed for which alternative techniques were the key feature (1928, 1945, 1951, 1966/Huggins, and 1976/Blumberg).

When the foregoing points are taken into consideration, less than 25 prizes remain on NSMR's list-a modest total indeed.

Nobel Prizes in medicine or physiology were also analyzed by the National Academy of Sciences (1985), in an assessment of the value of research employing various "model systems." The Academy concluded that studies of microorganisms and invertebrates (that is, less sentient organisms), as well as "lower vertebrates," have made great strides in our understanding of biology and medicine. Unfortunately, the report noted, "the proportion of $\mathrm{NIH}$ resources that supports research in this area may be small in comparison to the resources dedicated to research with mammals" (p. 75).

One of the Academy's conclusions was remarkably supportive of alternative techniques:

Proposals for the study of invertebrates, lower vertebrates, microorganisms, cell- and tissue-culture systems, or mathematical approaches should be regarded as having the same potential relevance to biomedical research as proposals for work on systems that are phylogenetically more closely related to humans (p. 75).

Researchers as well as funding agencies should heed this advice. Unfortunately many researchers currently consider alternative methods to be "adjuncts" to traditional animal research. The present paper suggests that this somewhat pejorative label should be dropped, and alternative methods should gain higher prominence in the researcher's armamentarium against biomedical ignorance.

This gain in prominence was predicted by Sir Peter Medawar, a Nobel Laureate in medicine or physiology. Although Medawar defended animal research and argued that its abolition would seriously impair research, he added:

... this does not imply that we are for evermore, and in increasing numbers, to enlist animals in the scientific service of man. I think that the use of experimental animals on the present scale is a temporary episode in biological and medical history, and that its peak will be reached in ten years' time, or perhaps even sooner (Medawar 1972). 
Medawar's words are especially relevant to his own field-immunology. Medawar used intact vertebrate animals in his prize-winning research, yet immunology is currently benefitting greatly from in vitro work (Garfield 1985; National Academy of Sciences 1985).

An expanded role for alternative techniques can transform biomedical research from an animal-centered enterprise to a human-centered one. Human-centered research would emphasize sophisticated clinical, epidemiological, and post-mortem studies, as well as tissue culture, mathematical modeling, and physicochemical studies of human material or human-derived data. Technical advances, such as positron emission tomography, are expanding the scope of sophisticated, non-invasive clinical studies.

\section{Conclusion}

Alternative techniques have made a major contribution to some of the twentieth century's most significant biomedical research. In some cases these techniques have substituted for the use of vertebrates; in other cases they have added to our biomedical knowledge in ways that were not feasible or practical using vertebrates.

The results provide a firm basis for expecting researchers to increase their reliance on alternative techniques and decrease their reliance on traditional animal research methods.

The ultimate goal of the alternatives approach should be human-centered research (as discussed above), with animal studies limited to naturalistic and clinical situations.

\section{Acknowledgements}

I extend my thanks to J. McArdle for suggesting that this analysis be undertaken and for commenting, along with A.N. Rowan, on an earlier draft of this manuscript. I also thank S. O'Berri, G. Lugbill, and C. Blair for secretarial assistance.

\section{Endnotes}

1 This paper is an expanded version of an analysis presented in Alternatives to Current Uses of Animals in Research, Safety Testing, and Education. (Washington, DC: The Humane Society of the United States, 1986.)

${ }^{2}$ Dr. Stephens is Associate Director, Laboratory Animal Welfare, The Humane Society of the United States, 2100 L St, NW, Washington, DC 20037.

${ }^{3}$ Despite the insight that Nicolle gained from his clinical observations, it is arguable that he would have been awarded a Nobel Prize without having demonstrated the louse's role using animals. However, this is largely a sociological issue, not a biomedical one. It testifies to the influence that Koch's postulates held among researchers (see Kuker-Reines 1982, p. 9). Today, the greater availability of alternative techniques often provides non-traditional means of demonstrating biological relationships, if such demonstrations are deemed necessary. We need to be more imaginative in our studies and less reliant on animals. 


\section{References}

Anonymous. 1986. Cocaine research on animals. Reverence for Life. March-April: 8-9.

Comroe, JH. and Dripps, RD. 1976. Scientific basis for the support of biomedical science. Science. 192: 105-11.

Drewett, R. and Kani, W. 1981. Animal experimentation in the behavioral sciences. In: Sperlinger, D. ed. Animals in Research: New Perspectives in Animal Experimentation. New York: John Wiley and Sons. pp. 175-201.

Gay, WI. ed. Undated. Health Benefits of Animal Research. Washington, DC: Foundation for Biomedical Research.

Giannelli, MA. 1985. Three blind mice, see how they run: A critique of behavioral research with animals. In: Fox, MW and Mickley, LD. eds. Advances in Animal Welfare Science, 1985-86. Washington, DC and Dordrecht, The Netherlands: The Humane Society of the United States and Martinus Nijhoff, respectively. pp. 109-64.

Kuker-Reines, B. 1982. Psycbology Experiments on Animals: A Critique of Animal Models of Human Psycbopathology. Boston: New England Anti-Vivisection Soc. (NEAVS).

Medawar, P. 1972. Quoted in Rowan (1979).

Miller, NE. 1985. The value of behavioral research on animals. Amer. Psych. 40(4): 423-40.

National Academy of Sciences. 1985. Models for Biomedical Research: A New' Perspective. Washington, DC: National Academy Press.

National Society for Medical Research. Undated. What do these Nobel Prize winners have in common? (Pamphlet). Washington, DC: NSMR.

Raub, W. Undated. Foreword. In: Gay, WI. ed. Health Benefits of Animal Research. Washington, DC: Foundation for Biomedical Research.

Reines, B. 1986. Cancer Research on Animals: Impact and Altematives. Chicago: National Anti-Vivisection Soc. (NAVS).

-. Undated. Heart Researcb on Animals: A Critique of Animal Models of Cardiovascular Disease. Jenkintown, PA: American Anti-Vivisection Soc. (AAVS).

Rowan, AN. 1979. Alternatives to Laboratory Animals: Definitions and Discussion. Washington, DC: Institute for the Study of Animal Problems.

Russell, WM. and Burch, RL. 1959. The Principles of Humane Experimental Technique. London: Methuen and Co.

Sharpe, R. 1985. The cruel deception. Animals' Defender and Anti-Vivisection News. May/June: 43-46.

Sourkes, TL. 1966. Nobel Prize Winners in Medicine and Pbysiology 1901-1965. New York: Abelard-Schuman.

Stephens, ML. 1986a. Maternal Deprivation Experiments in Psycbology: A Critique of Animal Models. Jenkintown, PA, Chicago, Boston : AAVS, NAVS, NEAVS, respectively.

- 1986b. Alternatives to Current Uses of Animals in Research, Safety Testing, and Education: A Layman's Guide. Washington, DC: The Humane Society of the United States. 